\title{
Emergence of Global Adaptive Governance for Stewardship of Regional Marine Resources
}

\author{
${\text { Henrik } \text { Öterblom }^{1} \text { and Carl Folke }}^{1,2}$
}

\begin{abstract}
Overfishing has historically caused widespread stock collapses in the Southern Ocean. Until recently, illegal, unreported, and unregulated (IUU) fishing threatened to result in the collapse of some of the few remaining valuable fish stocks in the region and vulnerable seabird populations. Currently, this unsustainable fishing has been reduced to less than $10 \%$ of former levels. We describe and analyze the emergence of the social-ecological governance system that made it possible to curb the fisheries crisis. For this purpose, we investigated the interplay between actors, social networks, organizations, and institutions in relation to environmental outcomes. We drew on a diversity of methods, including qualitative interviews, quantitative social network and survey data, and literature reviews. We found that the crisis triggered action of an informal group of actors over time, which led to a new organization (ISOFISH) that connected two independent networks (nongovermental organizations and the fishing industry), and later (COLTO) linked to an international body and convention (CCAMLR). The emergence of the global adaptive governance systems for stewardship of a regional marine resource took place over a 15-year period. We describe in detail the emergence process and illustrate the usefulness of analyzing four features of governance and understanding socialecological processes, thereby describing structures and functions, and their link to tangible environmental outcomes.
\end{abstract}

Key Words: CCAMLR; governance; IUU fishing; marine ecology; Southern Ocean; toothfish

\section{INTRODUCTION}

The world is characterized by increasing human pressure on, and demand for, ecosystem services (Rockström et al. 2009). It is of critical importance to understand fundamental design principles and the institutional architecture required for effective adaptive and multilevel governance of socialecological systems (Ostrom et al. 1999, Dietz et al. 2003, Ostrom 2009, Oberthür and Stokke 2011, Biermann et al. 2012). However, it is also important to understand pathways of change that lead to such governance (Folke et al. 2005, Olsson et al. 2008, Gelcich et al. 2010, Young 2010). A key question is related not only to what sustainable resource use implies when operational, but also how social-ecological systems can be moved towards more sustainable pathways. Although there are no panaceas (Ostrom et al. 2007), the current state of many ecosystems underline the urgency of an increased focus on the "how" question, which also has been identified as an underdeveloped area of research following the completion of the Institutional Dimension of Global Environmental Change project (Young 2008).

The study of different governance features and changes between such features has a long history (e.g., Young 1989, Pattberg and Stripple 2008, Young et al. 2008, Ahrne and Brunsson 2011). A number of recent studies at local (e.g., Olsson et al. 2004a, Olsson et al. 2006), international (Webster 2009, Young 2010), and global (e.g., Pattberg and Stripple 2008, Gulbrandsen 2009, Galaz et al. 2012) levels explicitly take on the "how" challenge, for a wide range of resources, with striking similarities in emergence patterns reported (compare e.g., Folke et al. 2005 with Galaz et al. 2012). These studies observe that institutions (the rules in use), regardless of geographical scale of operation, often consist of a number of diverse organizations and associated social networks that represent the individual actors, and their relations, involved in the governance effort (Crona and Hubacek 2010, Bodin and Prell 2011). Empirical work on the emergence of adaptive governance of social-ecological systems has illustrated the interdependence of these four features of governance-actors, networks, organizations, and institutions (e.g., Olsson et al. 2004b, Hahn et al. 2006). However, to our knowledge, there are few case studies on the emergence of global environmental adaptive governance that explicitly contain information on the interplay of these four features of governance (but see Peterson 1992 on the development of the International Whaling Commission).

This case study of the Southern Ocean draws on empirical sets of data derived from previous studies, which allows for an empirical analysis of the interplay of the four features. We analyze how actors, networks, organizations, and institutions combine to shape and influence governance processes and social-ecological change. Our hypothesis is that understanding interactions between these features helps in understanding patterns of emergence of adaptive governance for improved stewardship of ecosystems and the services they generate. Dietz et al. (2003) used the concept of adaptive governance to expand the focus from adaptive management of ecosystems to address the broader social contexts that enable ecosystem management. We specifically investigate the interactions between the features in the context of the Commission for the Conservation of Antarctic Marine Living Resources 
(CCAMLR) and the emergence of a global adaptive governance system in relation to illegal, unreported, and unregulated (IUU) fishing in the Southern Ocean (Fig. 1). Governance is the structures and processes by which people in societies make decisions and share power, and by governance we mean creating the conditions for ordered rule and collective action or institutions of social coordination (Folke et al. 2005). Following Dietz et al. (2003), adaptive governance refers to a process of dealing with complexity and change under uncertain conditions that are difficult to control, involving diverse interest groups, and reconciling conflict among people and groups who differ in values, interests, perspectives, and power, and the kinds of information they bring to situations. Previous studies of CCAMLR have illustrated that the emergence patterns described here have contributed to generating general features for robust governance, as defined in Fig. 3 of Dietz et al. (2003).

Fig. 1. A suspected illegal, unreported, and unregulated (IUU) vessel using long lines directed to catch Patagonian toothfish (Dissostichus eleginoides) but also resulting in seabird mortalities. The vessel was boarded by Australian government agencies. Copyright Australian Fisheries Management Authority, used with permission.

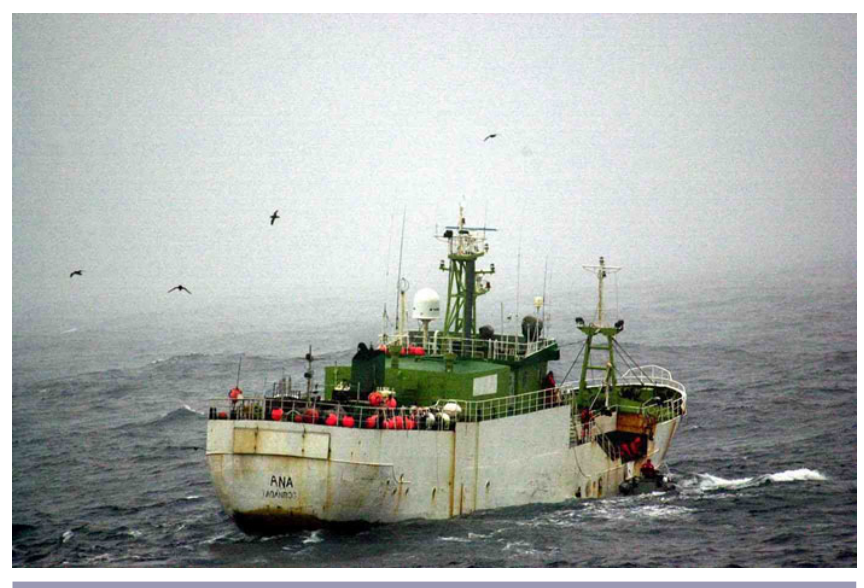

The transnational governance body of CCAMLR is responsible for the management of marine living resources in the Southern Ocean. The dynamics of this institution in relation to IUU fishing has been explored previously (e.g., Agnew 2000, Fallon and Kriwoken 2004, Österblom et al. 2010, 2011, Österblom and Sumaila 2011, Österblom and Bodin 2012). These studies used a range of methodologies, including qualitative interviews, quantitative social network and survey data, and literature reviews, which combined served as long-term empirical information for our analysis. Explicitly, these studies provided an understanding of the behavior of individual actors and how they, over time, mobilized their informal networks, which were later formalized into task-oriented organizations (Fallon and Kriwoken 2004, Österblom and Sumaila 2011), how crisis opened up policy windows for change and the emergence of formal and informal compliance mechanisms (Österblom and Sumaila 2011), how IUU fishermen continuously adapted to such mechanisms (Agnew 2000, Österblom et al. 2010), how re-conceptualization of the governance challenge created novel opportunities for change (Österblom et al. 2011), and how current patterns of cooperation between organizations is shaping outcomes (Österblom and Bodin 2012).

This empirical information has provided in-depth information and understanding that is now ripe to synthesize in relation to the four features of governance. Our purpose is to combine findings from earlier studies in relation to processes of emergence towards adaptive governance and the dynamic interplay between actors, networks, organizations, and institutions in this context. We attempt to understand the strengths and weaknesses of the respective four features in the process by investigating to what extent they contribute to institutional effectiveness, measured as tangible environmental outcomes. This case study illustrates how adaptive governance at the global scale has emerged and developed for improved management of regional ecosystem services. We discuss how studies of interplay between these four features of governance can contribute to understanding processes of emergence, regardless of geographical scale.

\section{EMPIRICAL OBSERVATIONS OF FOUR FEATURES OF GOVERNANCE}

Several empirical case studies have highlighted the importance of actors (individual people or groups), social networks (interactions between individuals or groups), organizations (a formalized entity with a collective goal), and institutions (norms and rules in use, formal and informal) for adaptive governance. The abbreviated definitions used may differ between scientific disciplines and theoretical perspectives. However, we have attempted to simplify observations from previous studies of human-environment interactions into the four features of governance to investigate whether they have any explanatory power-despite their complexity (and sometimes overlapping boundaries) in the rich governance literature. We focus on the process of emergence and underline that a study that addresses individuals or institutions only, may miss important aspects in understanding the process of emergence. We describe how individuals, by mobilizing social networks, formalizing cooperation, and integrating novel formal and informal rules create an adaptive governance system that enables complex problem solving.

\section{Actors}

The role of individual actors in governance, functioning as policy or institutional entrepreneurs and key individuals, has been well described (Kingdon 1984, Olsson et al. 2004a). Such 
individuals can contribute by providing capacity for innovation, functioning as agenda setters, and illustrating options for policy-making (Young 1991, Folke et al. 2005). A review of change processes in water management illustrates key roles and actions enabled by individual policy entrepreneurs who have an ability to develop attractive policy alternatives and manipulate or choose venues for enabling change (Meijerink and Huitema 2010). Through their good reputation and persistence, policy entrepreneurs can build social capital over time by creating trust and partnership, mobilizing support for the "cause," and solving conflict (Ostrom 1990, Meijerink and Huitema 2010). These leaders may be particularly important for creating meaning and communicating a common vision that other actors can relate to (Westley 1995). Policy entrepreneurs commonly use narratives strategically to frame a particular "world view" (Meijerink and Huitema 2010). Strong leadership has been identified as being critical for successful outcomes of governance efforts (Leach and Pelkey 2001, Gutierrez et al. 2011). Crises (whether ecological or political) can create policy windows or space for individual actors to emerge and influence governance outcomes (Kingdon 1984, Gunderson et al. 1995, Folke et al. 2005, Meijerink and Huitema 2010).

\section{Networks}

Individual actors who are able to generate social capital for a governance effort are likely involved in building, connecting, and maintaining social networks of relevance for managing the natural resource in question. Such networks often consist of diverse actors who form a "collective entrepreneurship" (cf. Meijerink and Huitema 2010) and operate at multiple geographic levels (Folke et al. 2005, Westley et al. 2011). Individual actors with similar ambitions, beliefs, values, and incentives will likely increasingly collaborate in informal social networks where they engage in information sharing and collaboration (Olsson et al. 2006). However, collaboration may also be the result of actors with divergent beliefs and values but with a shared interest in similar policy change, or that are dependent on the same resources (Meijerink and Huitema 2010). Social networks involved in policy development and implementation, commonly defined as policy networks (Rhodes 2007), have been widely described as highly relevant for successful outcomes in natural resource management (Olsson et al. 2004a, Olsson et al. 2006, Ernstson et al. 2008, Bodin and Crona 2009, Meijerink and Huitema 2010, Westley et al. 2011). It has been suggested that dormant social networks, or shadow networks, can be important sources of novelty and innovation, particularly in times of rapid change (Gunderson et al. 1995), when they can complement the roles filled by formal organizations and institutions (Kettl 2000, Hahn 2011). Such shadow networks have been identified as being critical for preparing systems for change (Olsson et al. 2006, Meijerink and Huitema 2010, Westley et al. 2011), and by doing so, enabling capacity of the governance system to adapt to rapidly emerging challenges.

\section{Organizations}

Social networks may increase their collaboration and evolve into more formalized organizations (Ahrne and Brunsson 2011, Galaz et al. 2012). Flexible organizations have been described as essential for the governance of complex adaptive social-ecological systems (Westley 1995, Dietz et al. 2003). Studies from local co-management efforts indicate that key actors can mobilize ad-hoc organizations, by drawing on his or her social (shadow) networks, to address rapidly emerging issues (Hahn et al. 2006). These organizations can provide critical boundary or bridging functions. Boundary organizations are particularly important for managing the boundaries between knowledge and action (Cash et al. 2003, Kristjanson et al. 2009), whereas bridging organizations can connect local actors and networks with other levels of governance (Olsson et al. 2004b, Olsson et al. 2008, Schultz et al. 2011, Crona and Parker 2012). Horizontal (e.g., between agencies or countries) or vertical (from local to national or national to global) interplay (Gehring and Oberthür 2008) may include the spread of specific tools or actions or may take the form of "cognitive interaction" - the spread of knowledge and ideas (Gehring and Oberthür 2008), analogous to the spread of world views and establishment of a common vision as described at the level of individual actors. The emergence and spread of such new perspectives can be initiated by reports that reveal new and critical insights on system properties, e. g., novel framing of existing challenges. Organizational change, based on changes in perceptions or mandates, has been studied in a range of disciplines in relation to adaptive ecosystem-based governance (Danter et al. 2000, Olsson et al. 2008, Kittinger et al. 2011). Organizations may operate independently of existing governance initiatives, or may become incorporated in existing governance efforts, where they are institutionalized as formal members. The integration of new organizations in existing institutions is a form of venue manipulation, which creates novel conditions for policy change (Meijerink and Huitema 2010).

\section{Institutions}

The study of institutional design principles in relation to natural resource management and social-ecological systems has been pioneered by Ostrom and colleagues in local and multiple-level management systems (Ostrom 1990, 1998, 2009, Ostrom et al. 1999), by Young and colleagues for international institutions, i.e., regimes (Young 1982, 1999, 2002a, 2002b, Young et al. 2008), and recently by Biermann and colleagues at the global scale (Biermann 2007, Biermann and Pattberg 2008, Biermann et al. 2012). Important insights that link design to successful outcomes have been generated. Key features of successful (effective) institutions include providing information, dealing with conflict, inducing compliance, providing infrastructure, and preparing for change (Breitmeier et al. 2006). Although the process of change in environmental institutions has received relatively little attention (Young et al. 2008), it is clear that this is a topic 
of great (and increasing) scientific interest, and which clearly illustrates the increasing role of nonstate organizations in shaping change in institutions (Young 1989, Peterson 1992, Pattberg and Stripple 2008, Webster 2009, Young 2010).

\section{CCAMLR-AN EMPIRICAL STUDY OF THE FOUR FEATURES OF GOVERNANCE}

CCAMLR was established in 1983 as part of the Antarctic Treaty System. CCAMLR is a forum for international collaboration between states, but nonstate actors are also included in national delegations and as independent observers. CCAMLR is thus a multilevel and polycentric governance structure (Österblom and Sumaila 2011). CCAMLR was put in place primarily to address a growing concern over a potentially rapid expansion of krill Euphausia superba harvesting but also the harvesting of other marine living resources (Miller et al. 2010). However, at the time of its establishment, several fish species had already been overexploited to the point of commercial extinction (Kock 1992, Ainley and Blight 2009). When toothfish Dissostichus spp. fisheries were developed in the Southern Ocean in the late 1980s and early 1990s, they provided a new opportunity for a profitable fishery (Agnew 2000). However, these valuable stocks also attracted a substantial IUU fishery, which at its peak was several times larger than the licensed toothfish fishery (Agnew 2000, Österblom and Sumaila 2011). IUU fishing threatened to result not only in a collapse of valuable toothfish stocks but also a number of globally threatened seabird species that were caught on baited hooks from IUU long lines (Miller et al. 2004). IUU fishing was first evident around South Georgia, but as it spread eastward, it increasingly became an international problem (Agnew 2000), which is the focus of this analysis. Dealing with IUU fishing in the Southern Ocean has been the main challenge for CCAMLR since the mid-1990s and a politically sensitive issue, as member states of CCAMLR have been identified as being involved in IUU operations, either as flag or port states, or by having their nationals involved in such operations (Österblom et al. 2010). CCAMLR is often described as a relatively well-functioning fisheries management institution compared to other, similar institutions (Cullis-Suzuki and Pauly 2010), and efforts to address IUU fishing have also generated substantial results, such as reducing IUU fishing by more than $90 \%$ (Fig. 2). Although estimates of IUU activities include uncertainties, there are several indications that suggest that this substantial reduction in IUU has occurred. It has been estimated that up to 90 vessels were active during the peak of IUU fishing (Agnew 2000), and a more recent report has identified between five and seven vessels as being active in the 2008/09, 2009/10, and 2010/11 seasons (CCAMLR 2009, 2010, 2011). These vessels use primarily gillnets rather than long lines, which has introduced uncertainty in current estimates of fish catches and seabird mortalities (CCAMLR 2011). The estimates of IUU fishing are based on a consistent methodology that takes a wide range of information sources into account. However, although monitoring capacity has substantially increased in the area due to recent advances in technology and investments in offshore infrastructure (Österblom and Sumaila 2011), it cannot be excluded that some vessels may operate without having been detected and are thus not included in official estimates.

Fig. 2. Official Commission for the Conservation of Antarctic Marine Living Resources (CCAMLR) estimates of illegal, unreported, and unregulated (IUU) fishing between 1995 and 2009 (SC-CAMLR 2010), and corresponding, simplified governance features as explained in the text. (a) Two independent networks of government (squares), nongovernmental organization (NGO) (circles), and fishing industry (triangles) actors were collaborating independently in the mid-1990s. (b) One network evolved into ISOFISH (solid black symbols and lines), and the two independent networks became connected. After ISOFISH, (c) the industry network was formalized to the Coalition of Legal Toothfish Operators (COLTO) (solid black symbols and lines), which contributed to CCAMLR as an effective institution (solid black symbols and lines). (d) The secretariat (hexagon) coordinates information flow.

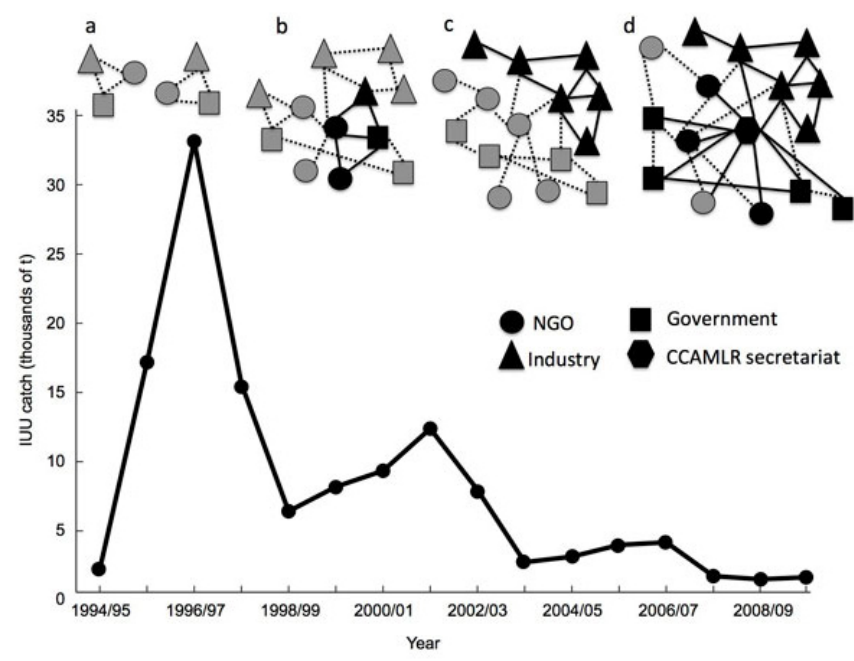

A reduction in IUU fishing has improved the prospects for a sustainable licensed fishery (Österblom and Sumaila 2011), and reduced IUU fishing also reduces seabird mortalities (Miller et al. 2004, SC-CAMLR 2007). The licensed fishing for toothfish is currently the most profitable fishery in the Southern Ocean and is unrivaled in value compared to other fisheries within the CCAMLR area (N. Slicer, personal communication).

Although CCAMLR existed before the emergence of welldocumented IUU fishing in the mid-1990s, it can be argued that it did not evolve into a well-functioning institution with 
the formal and informal mechanisms, tools, and information flows necessary to effectively deal with this challenge until more than a decade later (Österblom and Sumaila 2011, Österblom and Bodin 2012). How then, did this successful institution evolve? It is very clear that CCAMLR, as an institution, was initially unable to address IUU fishing effectively. Instead, CCAMLR served as a platform in which informal actors and networks were able to organize and contribute to the emergence of CCAMLR as an effective institution in dealing with IUU fishing. The process of this emergence drew on the four identified features of governance.

\section{Actors mobilize their networks}

When IUU fishing emerged in the mid-1990s, few individual actors had knowledge about the scope and potential impact of this fishery. The political will to address IUU fishing was initially constrained by a limited knowledge and consensus mechanisms in CCAMLR. An individual from a small nongovernmental organization (NGO) in Norway became committed to understanding the implications of this IUU fishing and, in 1996, managed to secure funding from the Norwegian government to investigate the actors involved in such fishing (Album 1997):

The reason I got engaged was that I was reading an article in a Norwegian local paper about Norwegians on the way to the Southern Ocean to go fishing, where I knew we had no quota. I started to investigate the issue, and was uncovering really interesting information. I had meetings with the Argentinean embassy about the Norwegian boats but they had no idea about it whatsoever. Governments seemed to know very little about this, and the same was true for the NGO community. The industry had more information, however.

This Norwegian NGO actor was able to use existing contacts with the fishing industry for the exchange of information. At the same time, NGO and fishing industry representatives participating in the Australian delegation to CCAMLR in 1997 quickly realized that IUU fishing was at a scale that posed a significant threat to populations of vulnerable fish stocks and seabirds. The Scientific Committee to CCAMLR clearly expressed their concerns for what appeared to be an evident collapse of albatross populations (due to bycatch in fishing gear) and toothfish stocks (SC-CAMLR 1997). However, to the nonstate actors in the Australian delegation, it was also clear that their, or any other, government would likely be unable to control the situation, until it was too late, due to political sensitivities associated with IUU fishing (e.g., Agnew 2000, Fallon and Kriwoken 2004, Österblom et al. 2010, Österblom and Bodin 2012). The Australian NGO and fishing representative quickly mobilized their networks to collect information. According to an NGO representative:
The NGOs witnessed the development and could clearly see that this was an impending disaster. We also realized that governments would be too slow and inadequate in their response. Together with the fishing industry, we rapidly pooled our resources. Our industry contacts did their share through providing their contacts that put their money and networks on the table. This provided phone access to industry actors around the world who were key players in the fishery.

The regional environmental challenge of IUU fishing in the late 1990s connected individual actors from the NGO community with their personal contacts, including key actors in the fishing industry, which lead to a rapid increase in information exchange and collaboration in two (originally independent) informal networks (Fig. 2a), i.e., one in Norway and one in Australia. Individual actors thus were able to connect with like-minded individuals, which lead to the emergence of an informal social networks aimed at reducing illegal fishing.

\section{Networks are formalized into organizations}

The Australian NGO was funded by the Australian government and fishing industry to launch a new organization called ISOFISH (Fallon and Kriwoken 2004). This organization benefited from the emerging social networks of associated actors from the fishing industry, environmental NGOs, scientific community, and government agencies (Fig. $2 b$ ), all of which were represented in the organization designed to address the commonly perceived crisis of IUU fishing. This network did not build primarily on shared beliefs and values but rather on synergies between environmental and commercial interests to reduce IUU fishing (thereby reducing seabird mortalities and improving commercial potential for a licensed fishery). The "shadow network" that lead to the formalization of ISOFISH and contributed information on IUU fishing provided important resources and carried out research for describing actors, vessels, ports, and countries involved in IUU fishing. This work clarified the nature of the problem and led to the proposal of a number of concrete policy measures, thereby preparing the system for change. A small number of governments were starting to collaborate frequently around this time (Fig. 2b). ISOFISH actively uncovered new information on IUU fishing and generated very substantial social and political pressure through their reports on IUU fishing to CCAMLR. Members of ISOFISH were also members of the Antarctic Southern Ocean Coalition (ASOC). This NGO network has observer status in CCAMLR and is regarded as a legitimate member of the Commission (Fallon and Kriwoken 2004). IUU fishing was not initially a major priority of ASOC, but ISOFISH could use this platform to communicate their reports to CCAMLR, thereby contributing to reframing issues and agendas of the Commission. Illegal 
fishing decreased substantially for a number of years, presumably due largely to the activities carried out by ISOFISH. ISOFISH contributed to making IUU fishing less socially acceptable in the fishing industry by targeting banks that financed such fishing and by stimulating political pressure within CCAMLR, which resulted in states deflagging vessels, increasing ports control, and changing their national legislation (Fallon and Kriwoken 2004, Österblom and Sumaila 2011). According to an NGO representative:

The strength of ISOFISH was that we could use information in a way which governments or industry could not do. No government could go public with the type of information we used. The lower burden of proof was the key to our success.

ISOFISH was closed down in 1999, in part as a consequence of a feeling of "mission completed"-IUU fishing had been substantially reduced (Fig. 2). An additional reason for closing down ISOFISH was the threat of lawsuits from fishing companies identified by the organization as fishing illegally. The small NGO leading ISOFISH would have been unable to sustain such legal actions, which illustrates the vulnerability of the organization. The social networks established and developed by ISOFISH remained, however. These shadow networks would prove important when IUU fishing subsequently re-emerged. In 2002, IUU fishing activities increased again. Vessels engaged in IUU fishing were now substantially better organized than they had been in the 1990s. Part of the shadow networks from ISOFISH were mobilized, and the fishing industry established the Coalition of Legal Toothfish Operators (COLTO) as a new international NGO with an aim to reduce IUU fishing (Fig. 2c). COLTO was created as a new forum for bringing the licensed toothfish industry together. According to Martin Exel at Austral Fisheries:

COLTO was created in May 2002, using contacts in the legal industry and ISOFISH contacts and assisted in spreading the message of the need to eliminate IUU fishing

A number of governments were increasingly cooperating on an ad-hoc basis around Southern Ocean sightings and arrests of vessels suspected of illegal fishing (Fig. 2c). These operations involved extensive cooperation between the Australian, French, South African, and UK navy in different constellations (Molenaar 2004). These joint international arrests could involve hot pursuits over hundreds of miles. Such "high profile" pursuits contributed to raising public and political awareness of IUU fishing. Private investigations carried out by COLTO were broadcast in a national television show in Australia (Masters 2002), which further stimulated national political pressure and international attention. Ideas for policy measures developed by nonstate actors could be linked to existing narratives related to border protection security (see Meijerink and Huitema 2010) during a time when such issues were high on the domestic political agenda (Österblom and Sumaila 2011). Some governments (notably Australia and France) even elaborated mutual formalized agreements for Southern Ocean monitoring and enforcement. IUU fishing became an increasingly important issue for a number of actors, which resulted in substantial investments in monitoring and control (ANAO 2008) (Fig. 3). During this time, additional ASOC members also mobilized to investigate and address IUU fishing, thereby generating important new knowledge (Lack and Sant 2001, NET 2004), and conducted campaigns against consumption of illegally caught toothfish - e.g., the campaign "Take a pass on Chilean Sea bass", launched in 2002 by the National Environmental Trust (Knecht 2006). Several networks and organizations thus mobilized their capacity to focus on IUU fishing in the Southern Ocean and were active both at the national and international level. This engagement of a wide range of organizations operating at multiple geographical scales and in different sectors created conditions for both horizontal and vertical interplay (cf. Gehring and Oberthür 2008). Such interplay and the capacity to use multiple venues for influencing policies are consistent with empirical observations from local (Meijerink and Huitema 2010) to international (Gehring and Oberthür 2008) levels.

Fig. 3. International cooperation has improved the possibilities for detection, apprehension, and conviction of illegal fishing operators. Monitoring and enforcement is conducted at sea and involves substantial cooperation between, for example, Australian government agencies (illustrated here) and French government agencies. Monitoring is also conducted using aerial patrols and satellite surveillance. Picture courtesy of the Australian Customs and Border Protection Service.

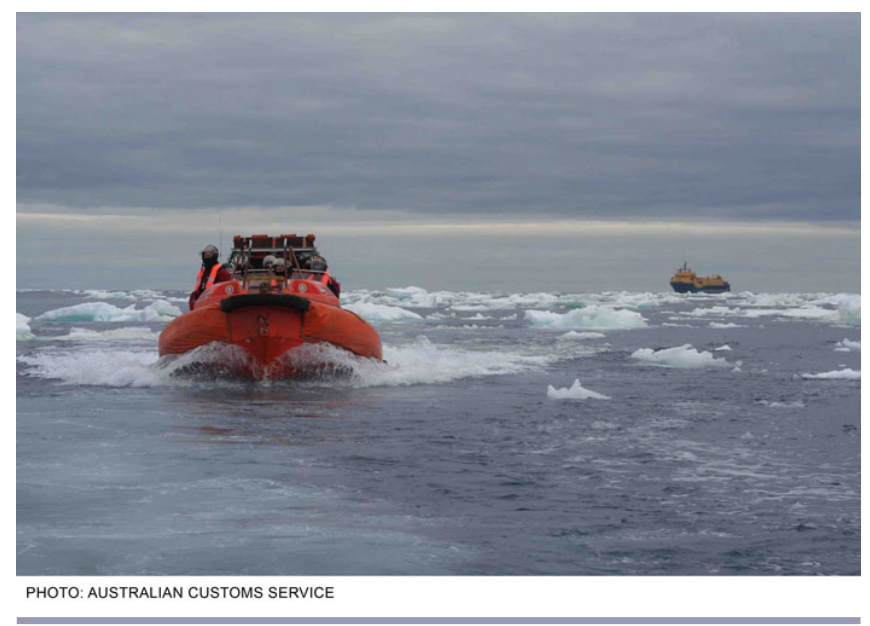




\section{Institutionalizing actors, networks, and organizations} The CCAMLR secretariat and governments in CCAMLR had been struggling for several years to establish an effective governance institution to address IUU fishing. This has proven to be challenging because IUU actors were flexible enough to adapt to management measures far more quickly than formal governance could be adopted (Österblom et al. 2010). The adaptive capacity of IUU actors underlines the importance of flexibility (Dietz et al. 2003). Individual actors, networks, and organizations described here have stimulated a capacity to be flexible. In 2000, CCAMLR developed a Catch Documentation Scheme (CDS) for tracking toothfish products (Agnew 2000), but due to initial loopholes, it was not effective until the loopholes were finally closed in 2004 (Miller et al. 2010). CCAMLR also developed a black list of IUU vessels (CCAMLR IUU list) dating back to 2003 (Miller et al. 2010). That same year, COLTO was accepted as a formal partner to the Commission by gaining official observer status (a form of venue manipulation [cf. Meijerink and Huitema 2010]). COLTO thus became part of the governance institution, where they presented a report that re-conceptualized IUU fishing as a form of organized crime (COLTO 2003), a powerful narrative with a capacity to mobilize substantial political support (Österblom et al. 2011) and which has been identified as a well-established current perception of IUU fishing in the region (Österblom and Bodin 2012). The CDS and IUU list became critical tools for mobilizing and utilizing the capacity and information that had been generated in the respective social networks between governments, NGOs, and industry organization over time. These tools function as boundary objects by lowering the threshold for cooperation and thereby stimulating both vertical and horizontal interplay (Österblom and Bodin 2012). Precursors of the IUU list include the ISOFISH Rouges Gallery list of suspected IUU vessels, which was further developed by ASOC in its IUU vessel red list prior to formal establishment of the official CCAMLR IUU list (Fallon and Kriwoken 2004). NGOs were also directly involved in the work that led to the establishment of the CDS (Agnew 2000). Using these tools, the CCAMLR secretariat has become empowered to function as an effective institution and has been operating as a central hub in the network of organizations that are collaborating to address IUU fishing in the Southern Ocean area (Österblom and Bodin 2012). Currently, a wide range of organizations is using information on vessel activities, trade flows, and IUU actors derived from both state and nonstate actors to detect, apprehend, and prosecute suspected IUU offenders (Fig. 2d) (Österblom and Bodin 2012). Substantial investment in monitoring and enforcement at sea (Fig. 3), combined with aerial and satellite surveillance, is providing a deterrent to IUU fishing. However, despite these efforts, a small number of IUU vessels are still active in the Southern Ocean, potentially in new areas (CCAMLR 2011).
Important social capital in CCAMLR was created and maintained by key actors operating in informal social networks, some of which have been formalized into official organizations. Informal and formal networks and organizations have been instrumental to the successful outcomes of CCAMLR, and have emerged as a consequence of long-term face-to-face cooperation (cf. Ostrom 1998). A much reduced IUU fishing (Fig. 2) is creating conditions for a valuable and well-regulated licensed fishery for toothfish (Fig. 4) as well as improved conditions for vulnerable seabirds (Fig. 5).

Fig. 4. Licensed fishing for toothfish, including both Patagonian and Antarctic toothfish (Dissostichus mawsoni), illustrated here, requires a number of strict management measures. Photo courtesy of Dr Stuart Hanchet, the National Institute of Water and Atmospheric Research (NIWA)

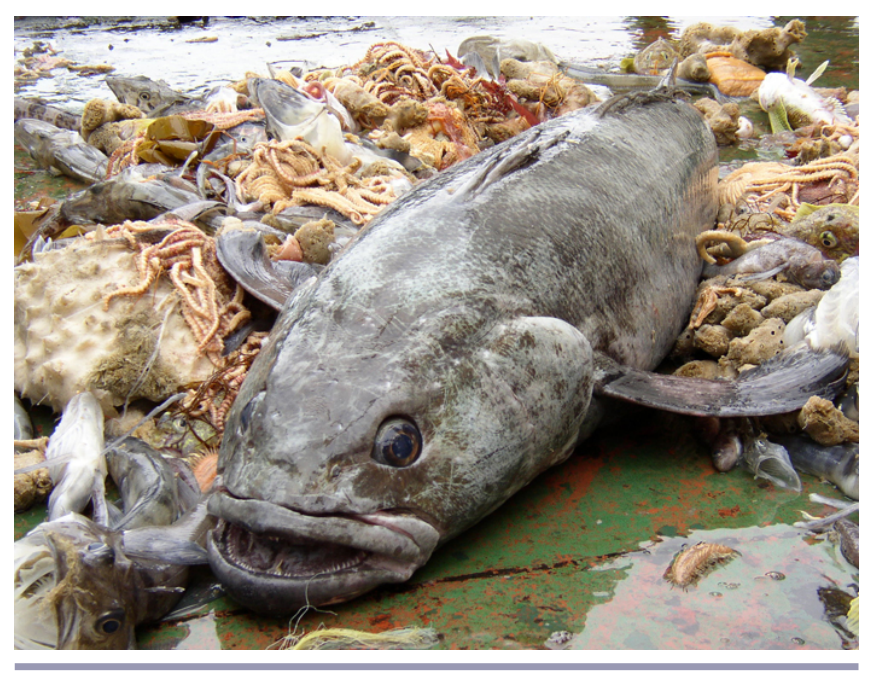

\section{LIMITATIONS AND ABILITIES IN FOUR FEATURES OF GOVERNANCE}

The strong focus on leadership, individuals, and informal networks in describing successful outcomes in socialecological systems (Folke et al. 2005, Gutierrez et al. 2011) raises the importance of accountability and legitimacy of such informal modes of operations (Hahn 2011). Provided they are perceived as legitimate and embedded in democratic structures, there is evidence to suggest that flexibility can be substantially enhanced by granting individual policy entrepreneurs room to maneuver within a governance system, and by mobilizing existing networks (Olsson et al. 2006, Fabricius et al. 2007). In this case study, rapid mobilization of shadow networks (pooling of competence between NGOs and the licensed fishing industry) created novel and complementary capacity to address a first crisis within CCAMLR (Österblom and Sumaila 2011). This crisis challenged the credibility of this institution, but it was unable 
Fig. 5. Grey-headed Albatross (or Grey-headed Mollymawk) (Thalassarche chrysostoma) is one of the species that previously suffered substantial mortalities in illegal, unreported, and unregulated (IUU) long lines. Photo: Rowan Trebilco/Azote.

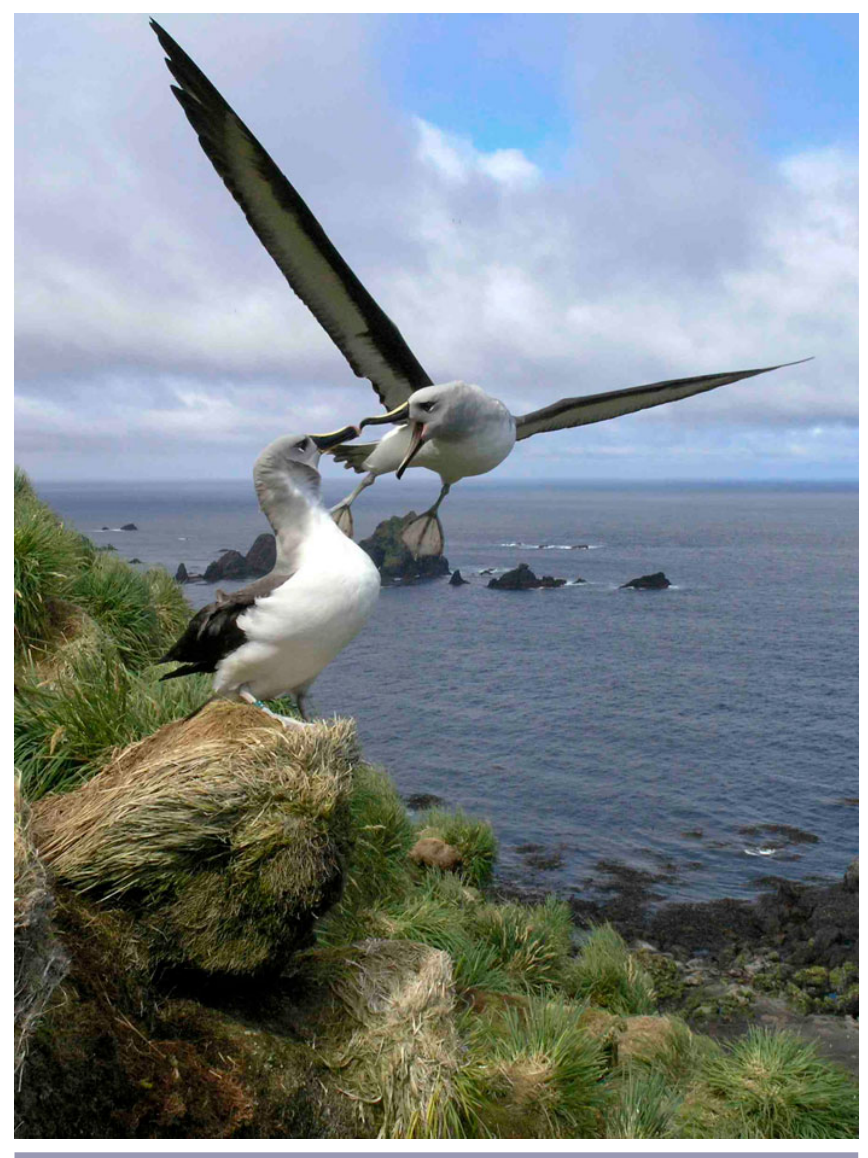

to design and implement policy measures at the scales required, which illustrated the commonly documented misfit between environmental challenges and institutions (Galaz et al. 2008). Formalized organizations, in turn, are likely to be less flexible but have a more clear definition of memberships, hierarchy, rules, monitoring, and sanctions than do networks with, e.g., unclear boundaries and rules (Ahrne and Brunsson 2011). The ISOFISH organization was continuously at risk of becoming subject to legal sanctioning by publishing highly controversial reports (Fallon and Kriwoken 2004). ISOFISH operated in multiple venues, which included conducting media campaigns in countries of suspected fishermen and through national and international political lobbying (Fallon and Kriwoken 2004). One mechanism by which ISOFISH was able to influence outcomes within CCAMLR was its association with ASOC, a legitimate and trusted observer, which provided a venue in the Commission where ISOFISH reports could be presented. COLTO has, since 2003, been able to provide information and influence policy discussions through its formal membership as observer to CCAMLR. Both ASOC and COLTO have been identified as important organizations for reducing IUU fishing in the region (Österblom and Bodin 2012). These nonstate actors can operate at both national and international levels due to their diverse membership (Österblom and Sumaila 2011). National government agencies working to address IUU fishing also collaborate horizontally across nations and vertically by influencing national, international, and global policy processes related to IUU fishing, although some international cooperation in the region has been suggested to be pushing the limits of international law (Gullett and Schofield 2007).

A formal institution consisting of multiple organizations with different agendas and priorities will, by definition, be more complicated to manage and less able to adapt to emerging challenges. However, a formalized institution such as CCAMLR, when faced with novel challenges, seems to draw on the collective capacity of numerous organizations and their associated networks and individual capacities, and by doing so can be a powerful force in shaping governance outcomes.

This case study is an example of the emergence of adaptive governance at the global level, where the goals appear to have been sufficiently clear, the threats sufficiently imminent to create crises that opened up windows of opportunity, and participants have shared interests and adequate incentives to contribute to institutional effectiveness (Österblom and Sumaila 2011, Österblom and Bodin 2012). Organizations collaborate in this institution with commonly agreed upon formats for cooperation and are coordinated by a central actor, i.e., the CCAMLR secretariat (Österblom and Bodin 2012). This governance architecture is substantially different from the relatively less successful (and more complex) global climate governance, which has limited coordination and lacks centralized structure of authority or procedures (Pattberg and Stripple 2008).

\section{GENERALIZABILITY}

A study of change processes in the International Whaling Commission (Peterson 1992) clearly illustrates the importance of individual actors and their associated networks in driving changes in perception and focus of the international cooperation related to the management of whales. Galaz et al. (2012) have illustrated how individual actors mobilize their networks with an ambition to influence the international policy-making community concerned with issues related to climate change, fisheries, and ocean acidification. An analogous study of international change processes in the Coral Triangle Initiative highlights the interplay between individuals, together with their networks and organizations, to influence the development of this initiative (Rosen and Olsson 2013). Similarly, interplay between individuals, 
organizations, and institutions has been described as a key mechanism for change in the rezoning of the Great Barrier Reef (Olsson et al. 2008). Institutional change for the Western Hawaiian Islands has been described as a process of changing perceptions and collaboration between different organizations tasked to build a new institution (Kittinger et al. 2011).

Although several of these recent studies of marine governance incorporate aspects of the described four features, we argue that a comprehensive understanding of change processes requires, as a minimum, an understanding of the dynamics at all these four features of the governance process. Individuals are always operating in their personal networks, and these networks can be formalized into organizations. Such organizations can further influence or become integrated in formalized institutions - which influence their ability to affect change. Cross-scale interactions between actors and institutions are hence necessary to understand in order to comprehensively describe dynamics at multiple scales (Folke et al. 2005, Gehring and Oberthür. 2008, Meijerink and Huitema 2010). The study of all four features in other case studies can also shed some light on an important question: Is there a "logical progression" of governance, where change processes are always driven by actors in informal networks, which if formalized into organizations can provide space to influence the dynamics of institutions-or which other patterns of change can be observed? Do these features constitute minimum requirements for adaptive governance, and are they generic features? This case study provides an optimistic narrative related to sustainability challenges as the power of individuals to influence change is evident in the empirical data and plays out at the global level for stewardship of a regional resource. A more comprehensive appreciation of when different features can influence dynamics in a governance system could assist in providing guidance for actors, networks, and organizations in their ambitions to enable institutional change.

\section{CONCLUSIONS}

In the case of CCAMLR, it is clear that the four features (actors, networks, organizations, and institutions) used here contribute to an understanding of important interacting features in the emergence of adaptive governance that addresses environmental challenges. The global level governance system has substantially improved the environmental outcomes of the ecosystem services of concern, the unsustainable exploitation of the Southern Ocean fish resources, and the associated bycatch of vulnerable seabirds. The study highlights the importance of fast and slow variables for adapting to change, including providing seed money (fast variable) for alternative governance trajectories (funding a phase change of an informal network to the ISOFISH organization) and building trust over time (slow variable) between organizations and individuals engaged in CCAMLR.
It is unclear to what extent experiences from CCAMLR can be replicated elsewhere for other resources and other geographical and temporal scales. However, our study analyzing a global adaptive governance system to curb a perceived regional environmental crisis emphasizes the interacting and dynamic relationships of individual key actors, like visionaries, leaders, and institutional entrepreneurs, and relationships with social networks, organizations, and institutions and their interplay in the emergence process. We propose that a focus on understanding the emergence and interplay of these features as part of the evolution of adaptive governance systems (Folke et al. 2005) can add to existing studies of social-ecological systems and their institutions (Young et al. 2008, Ostrom 2009), change (Young 2010), and effectiveness (Breitmeier et al. 2006). A focus on all four features will enable scientists to understand critical relationships between structure, function, and outcomes.

Responses to this article can be read online at: http://www.ecologyandsociety.org/issues/responses. php/5373

\section{Acknowledgments:}

This research was supported by Mistra through a core grant to the Stockholm Resilience Centre, a cross-faculty research center at Stockholm University, with additional funding provided by the Swedish Environmental Protection Agency, FORMAS, the Nippon Foundation, and the Kjell and Märta Beijer Foundation. This work was also partially supported by the Academy Program on the Ecological Economics of Global Change. The participation in interviews by individuals with extensive knowledge about the Southern Ocean was much appreciated. Comments by anonymous reviewers, Dr. A. Gouldson, and Dr. A. Sörbom provided valuable feedback on a previous version of this manuscript.

\section{LITERATURE CITED}

Agnew, D. J. 2000. The illegal and unregulated fishery for toothfish in the Southern Ocean, and the CCAMLR catch documentation scheme. Marine Policy 24:361-374.

Ahrne, G., and N. Brunsson. 2011. Organization outside organizations: the significance of partial organization. Organization 18:83-104. http://dx.doi.org/10.1177/1350508$\underline{410376256}$

Ainley, D. G., and L. K. Blight. 2009. Ecological repercussions of historical fish extraction from the Southern Ocean. Fish and Fisheries 10:13-38. http://dx.doi.org/10.1111/ j.1467-2979.2008.00293.x 
Album, G. 1997. Fisket etter Patagonian Toothfish og norske interesser (Fishing for Patagonian toothfish and Norwegian interests). Norges Naturvernforbund (Friends of the Earth, Norway), Oslo.

Australian National Audit Office (ANAO). 2008. Illegal, unreported and unregulated fishing in the Southern Ocean. Australian National Audit Office, Canberra,Australia.

Biermann, F. 2007. 'Earth system governance' as a crosscutting theme of global change research. Global Environmental Change, Part A: Human and Policy Dimensions 17:326-337. http://dx.doi.org/http://dx.doi.org/10.1016/ j.gloenvcha.2006.11.010

Biermann, F., and P. Pattberg. 2008. Global environmental governance: taking stock, moving forward. Annual Review of Environment and Resources 33:277-294. http://dx.doi. org/10.1146/annurev.environ.33.050707.085733

Biermann, F., K. Abbott, S. Andresen, K. Bäckstrand, S. Bernstein, M. M. Betsill, H. Bulkeley, B. Cashore, J. Clapp, C. Folke, A. Gupta, J. Gupta, P. M. Haas, A. Jordan, N. Kanie, T. Kluvánková-Oravská, L. Lebel, D. Liverman, J. Meadowcroft, R. B. Mitchell, P. Newell, S. Oberthür, L. Olsson, P. Pattberg, R. Sánchez-Rodríguez, H. Schroeder, A. Underdal, S. Camargo Vieira, C. Vogel, O. R. Young., A. Brock, and R. Zondervan. 2012. Navigating the Anthropocene: improving Earth system governance. Science 335:1306-1307. http://dx.doi.org/10.1126/science.1217255

Bodin, Ö., and B. I. Crona. 2009. The role of social networks in natural resource governance: What relational patterns make a difference? Global Environmental Change-Human and Policy Dimensions 19:366-374. http://dx.doi.org/http://dx. doi.org/10.1016/j.gloenvcha.2009.05.002

Bodin, Ö., and C. Prell. 2011. Social networks and natural resource management: uncovering the social fabric of environmental governance. Cambridge University Press, Cambridge, UK. http://dx.doi.org/10.1017/CBO9780511894985

Breitmeier, H., O. Young, and M. Zürn. 2006. Analyzing international environmental regimes-from case study to database. The MIT Press, Cambridge, Massachusetts, USA.

Cash, D. W., W. C. Clark, F. Alcock, N. M. Dickson, N. Eckley, D. H. Guston, J. Jager, and R. B. Mitchell. 2003. Knowledge systems for sustainable development. Proceedings of the National Academy of Sciences of the United States of America 100:8086-8091. http://dx.doi.org/10.1073/pnas.1231332100

Coalition of Legal Toothfish Operators (COLTO). 2003. Rogues gallery: the new face of IUU fishing for toothfish. COLTO, Mount Hawthorn, Western Australia.

Commission for the Conservation of Antarctic Marine Living Resources (CCAMLR). 2009. Report of the twenty-eight meeting of the Commission. CCAMLR, Hobart, Tasmania, Australia.

Commission for the Conservation of Antarctic Marine Living Resources (CCAMLR). 2010. Report of the twenty-ninth meeting of the Commission. CCAMLR, Hobart, Tasmania, Australia.

Commission for the Conservation of Antarctic Marine Living Resources (CCAMLR). 2011. Report of the thirtieth meeting of the Commission. CCAMLR, Hobart, Tasmania, Australia.

Crona, B. I., and K. Hubacek. 2010. The right connections: How do social networks lubricate the machinery of natural resource governance? Ecology and Society 15(4):18. [online] URL: http://www.ecologyandsociety.org/vol15/iss4/art18/

Crona, B. I., and J. N. Parker. 2012. Learning in support of governance: theories, methods, and a framework to assess how bridging organizations contribute to adaptive resource governance. Ecology and Society 17(1):32. [online] URL: http://dx.doi.org/10.5751/ES-04534-170132

Cullis-Suzuki, S., and D. Pauly. 2010. Failing the high seas: a global evaluation of regional fisheries management organizations. Marine Policy 34:1036-1042. http://dx.doi. org/10.1016/j.marpol.2010.03.002

Danter, K. J., D. L. Griest, G. W. Mullins, and E. Norland. 2000. Organizational change as a component of ecosystem management. Society \& Natural Resources 13:537-547. http://dx.doi.org/http://dx.doi.org/10.1080/08941920050114592

Dietz, T., E. Ostrom, and P. C. Stern. 2003. The struggle to govern the commons. Science 302:1907-1912. http://dx.doi. org/10.1126/science.1091015

Ernstson, H., S. Sörlin, and T. Elmqvist. 2008. Social movements and ecosystem services-the role of social network structure in protecting and managing urban green areas in Stockholm Ecology and Society 13(2):39. [online] URL: http://www.ecologyandsociety.org/vol13/iss2/art39/

Fabricius, C., C. Folke, G. Cundill, and L. Schultz. 2007. Powerless spectators, coping actors, and adaptive comanagers: a synthesis of the role of communities in ecosystem management. Ecology and Society 12(1):29. [online] URL: http://www.ecologyandsociety.org/vol12/iss1/art29/

Fallon, L., and L. Kriwoken. 2004. International influence of an Australian nongovernment organization in the protection of Patagonian toothfish. Ocean Development and International Law 35:221-266. http://dx.doi.org/10.1080/00908320490467323

Folke, C., T. Hahn, P. Olsson, and J. Norberg. 2005. Adaptive governance of social-ecological systems. Annual Review of Environment and Resources 30:441-473. http://dx.doi. org/10.1146/annurev.energy.30.050504.144511 
Galaz, V., B. Crona, H. Österblom, P. Olsson, and C. Folke. 2012. Polycentric systems and interacting planetary boundaries-emerging governance of climate change-ocean acidification-marine biodiversity. Ecological Economics 81:21-32. http://dx.doi.org/10.1016/j.ecolecon.2011.11.012

Galaz, V., P. Olsson, T. Hahn, C. Folke, and U. Svedin. 2008. The problem of fit among biophysical systems, environmental and resource regimes, and broader governance systems: insights and emerging challenges in O. R. Young, $\mathrm{H}$. Schroeder, and L. A. King, editors. Institutions and environmental change-principal findings, applications, and research frontiers. The MIT Press, Cambridge, Massachusetts, USA.

Gehring, T., and S. Oberthür. 2008. Interplay: exploring institutional interactions in O. R. Young, H. Schroeder, and L. A. King, editors. Institutions and environmental changeprincipal findings, applications, and research frontiers. The MIT Press, Cambridge, Massachusetts, USA.

Gelcich, S., T. P. Hughes, P. Olsson, C. Folke, O. Defeo, M. Fernandez, S. Foale, L. H. Gunderson, C. Rodriguez-Sickert, M. Scheffer, R. S. Steneck, and J. C. Castilla. 2010. Navigating transformations in governance of Chilean marine coastal resources. Proceedings of the National Academy of Sciences of the United States of America 107:16794-16799. http://dx. doi.org/10.1073/pnas.1012021107

Gulbrandsen, L. H. 2009. The emergence and effectiveness of the Marine Stewardship Council. Marine Policy 33: 645-660. http://dx.doi.org/10.1016/j.marpol.2009.01.002

Gullett, W., and C. Schofield. 2007. Pushing the limits of the Law of the Sea convention: Australian and French cooperative surveillance and enforcement in the Southern Ocean. The International Journal of Marine and Coastal Law 22:545583. http://dx.doi.org/10.1163/157180807782512224

Gunderson, L., C. S. Holling, and S. Light. 1995. Barriers and bridges to the renewal of ecosystems and institutions. Columbia University Press, New York, New York, USA.

Gutierrez, N. L., R. Hilborn, and O. Defeo. 2011. Leadership, social capital and incentives promote successful fisheries. Nature 470:386-389. http://dx.doi.org/10.1038/nature09689

Hahn, T. 2011. Self-organized governance networks for ecosystem management: Who is accountable? Ecology and Society 16(2):18. [online] URL: http://www.ecologyandsociety. org/vol16/iss2/art18/

Hahn, T., P. Olsson, C. Folke, and K. Johansson. 2006. Trustbuilding, knowledge generation and organizational innovations: the role of a bridging organization for adaptive comanagement of a wetland landscape around Kristianstad, Sweden. Human Ecology 34:573-592. http://dx.doi. org/10.1007/s10745-006-9035-Z
Kettl, D. F. 2000. The transformation of governance: globalization, devolution, and the role of government. Public Administration Review 60:488-497. http://dx.doi. org/10.1111/0033-3352.00112

Kingdon, J. W. 1984. Agendas, alternatives and public policies. HarperCollins College Publishers, New York, New York, USA.

Kittinger, J. N., A. Dowling, A. R. Purves, N. A. Milne, and P. Olsson. 2011. Marine protected areas, multiple-agency management, and monumental surprise in the northwestern Hawaiian Islands. Journal of Marine Biology 2011. 17 pp. http://dx.doi.org/10.1155/2011/241374

Knecht, G. B. 2006. Hooked: pirates, poaching and the perfect fish. Rodale, Emmaus, Pennsylvania, USA.

Kock, K.-H. 1992. Antarctic fish and fisheries. Cambridge University Press, Cambridge, USA.

Kristjanson, P., R. S. Reid, N. Dickson, W. C. Clark, D. Romney, R. Puskur, S. MacMillan, and D. Grace. 2009. Linking international agricultural research knowledge with action for sustainable development. Proceedings of the National Academy of Sciences of the United States of America 106:5047-5052. http://dx.doi.org/10.1073/pnas.0807414106

Lack, M., and G. Sant. 2001. Patagonian toothfish: Are conservation and trade measures working? TRAFFIC Bulletin 19:1-19.

Leach, W. D., and N. W. Pelkey. 2001. Making watershed partnerships work: a review of the empirical literature. Journal of Water Resources Planning \& Management 127:378-385. http://dx.doi.org/10.1061/(ASCE)0733-9496(2001)127:6(378)

Masters, C. 2002. The toothfish pirates. Australian Broadcasting Corporation, Australia.

Meijerink, S., and D. Huitema. 2010. Policy entrepreneurs and change strategies: lessons from sixteen case studies of water transitions around the globe. Ecology and Society 15(2):21. [online] URL: http://www.ecologyandsociety.org/vol15/ iss $2 / \operatorname{art} 21 /$

Miller, D. G. M., E. N. Sabourenkov, and D. C. Ramm. 2004, Managing Antarctic marine living resources: the CCAMLR approach. The International Journal of Marine and Coastal Law 19:317-363. http://dx.doi.org/http://dx.doi. org/10.1163/1571808042886075

Miller, D. G. M., N. Slicer, and E. Sabourenkov. 2010. IUU fishing in Antarctic waters: actions and regulations by CCAMLR. in D. Vidas, editor. Law, Technology and Science for Oceans in Globalisation. Brill Academic Publishers. http:// dx.doi.org/10.1163/ej.9789004180406.i-610.53

Molenaar, E. J. 2004. Multilateral hot pursuit and illegal fishing in the Southern Ocean: the pursuits of the Viarsa 1 and 
the South Tomi. International Journal of Marine and Coastal Law 19:19-42. http://dx.doi.org/10.1163/157180804773788655

National Environmental Trust (NET). 2004. Black market for white gold: the illegal trade in Chilean sea bass. National Environmental Trust, Washington, D.C., USA.

Oberthür S., and O. S. Stokke, editors. 2011. Managing institutional complexity: regime interplay and global environmental change. The MIT Press, Cambridge, Massachusetts, USA.

Olsson, P., C. Folke, and F. Berkes. 2004a. Adaptive comanagement for building resilience in social-ecological systems. Environmental Management 34:75-90. http://dx.doi. org/http://dx.doi.org/10.1007/s00267-003-0101-7

Olsson, P., C. Folke, and T. Hahn. 2004b. Social-ecological transformation for ecosystem management: the development of adaptive co-management of a wetland landscape in southern Sweden. Ecology and Society 9(4):2 [online] URL: http:// www.ecologyandsociety.org/vol9/iss4/art2/

Olsson, P., C. Folke, and T. P. Hughes. 2008. Navigating the transition to ecosystem-based management of the Great Barrier Reef, Australia. Proceedings of the National Academy of Sciences of the United States of America 105:9489-9494. http://dx.doi.org/10.1073/pnas.0706905105

Olsson, P., L. H. Gunderson, S. R. Carpenter, P. Ryan, L. Lebel, C. Folke, and C. S. Holling. 2006. Shooting the rapids: Navigating transitions to adaptive governance of socialecological systems. Ecology and Society 11(1):18. [online] URL: http://www.ecologyandsociety.org/vol11/iss1/art18/

Österblom, H., and Ö. Bodin. 2012. Global cooperation among diverse organizations to reduce illegal fishing in the Southern Ocean. Conservation Biology 26:638-648. http://dx.doi. org/10.1111/j.1523-1739.2012.01850.x

Österblom, H., A. Constable, and S. Fukumi 2011. Illegal fishing and the organized crime analogy. Trends in Ecology and Evolution 26: 261-262. http://dx.doi.org/http://dx.doi. org/10.1016/j.tree.2011.03.017

Österblom, H., and U. R. Sumaila. 2011. Toothfish crises, actor diversity and the emergence of compliance mechanisms in the Southern Ocean. Global Environmental Change 21:972-982. http://dx.doi.org/10.1016/j.gloenvcha.2011.04.013

Österblom, H., U. R. Sumaila, Ö. Bodin, J. Hentati Sundberg, and A. J. Press. 2010. Adapting to regional enforcement: fishing down the governance index. PLOS ONE 5:e12832. http://dx.doi.org/http://dx.doi.org/10.1371/journal.pone.0012832

Ostrom, E. 1990. Governing the commons. The evolution of institutions for collective action. Cambridge University Press, Cambridge, UK. http://dx.doi.org/10.1017/CBO9780511807763
Ostrom, E. 1998. A behavioral approach to the rational choice theory of collective action. American Political Science Review 92:1-22. http://dx.doi.org/10.2307/2585925

Ostrom, E. 2009. A general framework for analyzing sustainability of social-ecological systems. Science 325:419422. http://dx.doi.org/10.1126/science.1172133

Ostrom, E., J. Burger, C. B. Field, R. B. Norgaard, and D. Policansky. 1999. Revisiting the commons: local lessons, global challenges. Science 284:278-282. http://dx.doi. org/10.1126/science.284.5412.278

Ostrom, E., T. Dietz, N. Dolsak, P. C. Stern, S. Stonich, and E. U. Weber. 2002. The drama of the commons. National Academy Press, Washington, D.C., USA.

Ostrom, E., M. A. Janssen, and J. M. Anderies. 2007. Going beyond panaceas. Proceedings of the National Academy of Sciences of the United States of America 104:15176-15178. http://dx.doi.org/10.1073/pnas.0701886104

Pattberg, P., and J. Stripple. 2008. Beyond the public and private divide: remapping transnational climate governance in the 21st century. International Environmental Agreements 8:367-388. http://dx.doi.org/10.1007/s10784-008-9085-3

Peterson, M. J. 1992. Whalers, cetologists, environmentalists, and the international management of whaling. International Organization 46:147-186. http://dx.doi.org/10.1017/

$\underline{\text { S0020818300001478 }}$

Rhodes, R. A. W. 2007. Understanding governance: ten years on. Organization Studies 28:1243-1264. http://dx.doi. org/10.1177/0170840607076586

Rockström, J., W. Steffen, K. Noone, A. Persson, F. S. Chapin, E. F. Lambin, T. M. Lenton, M. Scheffer, C. Folke, H. J. Schellnhuber, B. Nykvist, C. A. de Wit, T. Hughes, S. van der Leeuw, H. Rodhe, S. Sorlin, P. K. Snyder, R. Costanza, U. Svedin, M. Falkenmark, L. Karlberg, R. W. Corell, V. J. Fabry, J. Hansen, B. Walker, D. Liverman, K. Richardson, P. Crutzen, and J. A. Foley. 2009. A safe operating space for humanity. Nature 461:472-475. http://dx.doi.org/10.1038/461472a

Rosen, F., and P. Olsson. 2013. Institutional entrepreneurs, global networks, and the emergence of international institutions for ecosystem-based management: the Coral Triangle Initiative. Marine Policy 38:195-204. http://dx.doi. org/10.1016/j.marpol.2012.05.036

Schultz, L., A. Duit, and C. Folke. 2011. Participation, adaptive co-management, and management performance in the world network of biosphere reserves. World Development 39:662-671. http://dx.doi.org/10.1016/j.worlddev.2010.09.014

Science Committee-Commission for the Conservation of Antarctic Marine Living Resources (SC-CAMLR). 1997. 
Report of the sixteenth meeting of the scientific committee. SC-CAMLR, Hobart, Tasmania, Australia.

Science Committee-Commission for the Conservation of Antarctic Marine Living Resources (SC-CAMLR). 2007. Report of the twenty-sixth meeting of the scientific committee. CCAMLR, Hobart, Tasmania, Australia.

Science Committee-Commission for the Conservation of Antarctic Marine Living Resources (SC-CAMLR). 2010. Report of the twenty-ninth meeting of the scientific committee. SC-CAMLR, Hobart, Tasmania, Australia.

Webster, D. G. 2009. Adaptive governance: the dynamics of Atlantic fisheries management. The MIT Press, Cambridge, Massachusetts, USA.

Westley, F. 1995. Governing design: the management of social system and ecosystem management. Pages 391-427 in L. Gunderson, C. S. Holling, and S. Light, editors. Barriers and bridges to the renewal of ecosystems and institutions. Columbia University Press, New York, New York, USA.

Westley, F., P. Olsson, C. Folke, T. Homer-Dixon, H. Vredenburg, D. Loorbach, J. Thompson, M. Nilsson, E. Lambin, J. Sendizmir, B. Banarjeee, V. Galaz, and S. van der Leeuw. 2011. Tipping towards sustainability: emerging pathways of transformation. Ambio 40:762-780. http://dx.doi. org/10.1007/s13280-011-0186-9

Young, O. 1982. Resource regimes-natural resources and social institutions. University of California Press, Berkeley, California, USA.

Young, O. R. 1989. The politics of international regime formation: managing natural resources and the environment. International Organization 43:349-375. http://dx.doi. org/10.1017/S0020818300032963

Young, O. R. 1991. Political leadership and regime formation: on the development of institutions in international society. International Organization 45:281-308. http://dx.doi. org/10.1017/S0020818300033117

Young, O. 1999. The effectiveness of international environmental regimes: causal connections and behavioral mechanisms. The MIT Press, Cambridge, Massachusetts, USA.

Young, O. R. 2002a. Evaluating the success of international environmental regimes: Where are we now? Global Environmental Change 12:73-77. http://dx.doi.org/http://dx. doi.org/10.1016/S0959-3780(01)00017-6

Young, O. R. 2002b. The institutional dimension of environmental change-fit, interplay and scale. The MIT Press, Cambridge, Massachusetts, USA and London, UK.

Young, O. R. 2008. Building regimes for socioecological systems: institutional diagnosis in O. R. Young, H. Schroeder, and L. A. King, editors. Institutions and environmental change - principalfindings, applications, and research frontiers. The MIT Press, Cambridge, Massachusetts, USA.

Young, O. R. 2010. Institutional dynamics. Emergent patterns in international environmental governance. The MIT Press, Cambridge, Massachusetts, USA.

Young, O. R., H. Schroeder, and L. A. King. 2008. Institutions and environmental change - principal findings, applications, and research frontiers. The MIT Press, Cambridge, Massachusetts, USA. 